\title{
The response to Histone deacetylase inhibitor in I matinib resistant, BCR-ABL independent, K562 variant with high levels of phosphorylated P38
}

\author{
Esther Rabizadeh ${ }^{1,2}$, Adina Aviram ${ }^{1,2}$, I nessa Belyaev, 2, Vita Mirkin², Yael Zimra ${ }^{1,2}$ \\ 1. Hematology Laboratory, Rabin Medical Center, Beilinson Campus, Petah Tikva, Israel. \\ 2. Department of Hemato-Oncology Laboratory, Felsenstein Medical Research Center, Tel Aviv University, Rabin Medical \\ Center, Petah Tikva, Israel.
}

Correspondence: Esther Rabizadeh. Address: Hematology Laboratory, Rabin Medical Center Beilinson Campus, Petah Tikva, Israel. E-mail: erabi@clalit.org.il

Received: October 14, 2012

Accepted: November 12, 2012

Online Published: November 20, 2012

DOI : $10.5430 /$ jhm.v2n4p33

URL: http://dx.doi.org/10.5430/jhm.v2n4p33

\section{Abstract}

Background: Imatinib mesylate, a TK inhibitor, is the main treatment for chronic myelogenous leukemia (CML), but patients may develop drug resistance. Mutations within the Abl kinase domain, increased expression of BCR-ABL or other regulatory mechanisms were suggested to be involved. However, recently the importance of BCR-ABL independent mechanisms in Imatinib resistance has been suggested. Exploring the role of proteins involved in BCR-ABL independent resistance is of great importance in designing new modalities to overcome resistance or potentiate TKI efficacy.

Cell model and Methods: In order to investigate the mechanisms of resistance, we developed an Imatinib resistant K562 cell line (K562-R). We focused on the involvement of BCR-ABL protein and p38 phosphorylation in K562-R resistance and the response to histone deacetylase inhibitor (HDACI). Cellular and molecular studies were conducted using flow cytometer, protein array, and RT-PCR and sequence analysis.

Results: Continuous exposure of K562-S to Imatinib mesylate resulted in an emerging sub-clone resistant to the drug. The acquired resistance was found to be independent of BCR-ABL. K562-R exhibited elevated spontaneous apoptosis in correlation with elevated levels of phosphor-p38 and a significant decrease in the expression of Wilms' tumor (WT1). Interestingly, the extent of apoptosis induction by HDACI was significantly higher in K562-R than in K562-S cells. HDACI induced phosphorylation of p38 in both cells. Nevertheless, inhibition of phosphor-p38 by SB203510 did not affect the response to HDACI neither in K562-S nor in K562-R cells.

Conclusions: Our data suggests that phospor-p38 do not play a major role in the apoptosis induced by this HDACI in K562-S and K562-R cells. However, the potentiated response of HDACI in K562-R cells may have an implication for combined therapy design in CML treatment. Further investigation on the role of proteins associated with apoptosis pathways may have important implications in future design of new modalities to overcome resistance or potentiate TKI efficacy.

\section{Key words}

Imatinib-resistance, BCR-ABL, HDACI, K562 


\section{Introduction}

Chronic myelogenous leukemia (CML) is associated with the chimeric, BCR-ABL protein, with high tyrosine-kinase (TK) activity ${ }^{[1]}$. Imatinib mesylate is a TK inhibitor and serves as the main treatment for CML. However, $5-10 \%$ of patients acquire resistance to the drug, and suboptimal response is observed in up to $20 \%$ of the patients. This may be due to either increased expression or mutations in BCR-ABL TK domain. However, other Imatinib resistance mechanisms that do not involve BCR-ABL have been described ${ }^{[2-4]}$. Studies of these mechanisms are of great importance in the design of drug therapy for CML.

One possible approach to overcome Imatinib resistance involves the combination of Histone Deacetylase Inhibitors (HDACI). Many malignancies, particularly leukemia, are associated with aberrant recruitment of HDAC ${ }^{[5]}$. It has been also shown that the transcription factor Wilms' tumor (WT1), which is highly expressed in leukemia and is induced by oncogenic signaling from BCR-ABL, contributes to the resistance against apoptosis induction by Imatinib ${ }^{[6]}$.

Recent studies have suggested the involvement of the mitogen-activated protein kinase (MAPK) family in Imatinib resistance. The proper functioning of members of the p38 family of MAPK is required for regulation of apoptosis, cell cycle arrest and induction of cell differentiation in response to stress signals ${ }^{[7]}$. Therefore, the involvement of $\mathrm{p} 38$ in imatinib resistance and Imatinib and HDACI induced apoptosis was investigated. As a model for CML resistance we developed an Imatinib-resistant variant of K562 (K562-R) which is a CML cell line expressing BCR-ABL.

The aim of the study was to determine whether BCR-ABL kinase domain mutation, or over expression of it or its target proteins are involved in the acquired resistance of K562-R cells, and whether the p38 pathway contributes to the resistance. The effect of HDACI on K562-R cells was studied as well.

\section{Cell model and methods}

\subsection{Cell cultures}

As a model for CML resistance we developed an Imatinib-resistant variant of K562. This was achieved by culturing K562 parental (K562-S) cells in RPMI medium with $10 \%$ FCS and $1 \%$ glutamine in the presence of gradually elevated concentrations of Imatinib $(0.1 \mu \mathrm{M}$ to the final concentration of $2 \mu \mathrm{M})$ for 7 months based on previous experience ${ }^{[5,8]}$. The cells were under the same conditions as K562-S cells, but supplemented with $2 \mu \mathrm{M}$ Imatinib. K562-R cells were incubated in the absence of Imatinib in the medium for 3 days prior to all experiments. Both cell lines were cultured at $2.5 \times 10^{5}$ cells $/ \mathrm{mL}$, at $37^{\circ} \mathrm{C}$ in a humidified $5 \% \mathrm{CO}_{2}$ incubator for various intervals with or without pivaloyloxymethyl butyrate, a HDACI, and Imatinib.

\subsection{Viable cell number analysis}

Cell viability assays were conducted in order to evaluate K562-R resistance to Imatinib and the response to other agents. Viable cells were determined by trypan blue exclusion test and Alamar blue, according to the manufacturer's instructions (SeroTec BFU012B). The results are presented as percentage of control values.

\subsection{Apoptosis induction}

Apoptosis induction was measured by 2 methods:

I. IQ Phosphatidyl Serine Detection kit (Annexin V; IQP Products Groningen, Netherland). The analysis was conducted by flow cytometer according to the manufacturer's instructions and analyzed with Lysis software (Becton Dickinson, Franklin Lakes, NJ, USA). 
II. Caspase-3 activity: Caspase activity was analyzed in cell lysates containing 30-100 $\mu \mathrm{g}$ protein incubated with $100 \mu \mathrm{M}$ of substrate (Ac-DEVD-AMC) at $37^{\circ} \mathrm{C}$. The hydrolysis of the substrate was followed by fluorescence detection: $380 \mathrm{~nm}$ (excitation) and 460 (emission) in a CytoFluor fluorescence plate reader.

\subsection{BCR-ABL protein and transcript}

$\mathrm{BCR}$ ABL protein and transcript levels, as well as mutation status were analyzed in order to determine the possible involvement of this main CML target in the resistance. The immediate phosphor targets of BCR-ABL cascade were also analyzed.

\subsection{BCR-ABL protein analysis by immunoblotting}

Two primary antibodies were used for detection of the BCR-ABL chimeric protein: anti-Bcr mouse monoclonal antibody (Ab-2, OP26) and anti-Abl mouse monoclonal antibody (Ab-2, OP19) (Oncogene Science, Bar Harbor, MA, USA), at $2 \mu \mathrm{g} / \mathrm{mL}$ each. Secondary fluorescent antibodies were: goat anti-mouse (Oncogen Science, MA, USA) at a dilution of 1:500-1:1000 and goat anti-rabbit (New England Biolabs, Ipswich, MA, USA) at a dilution of 1:500. Western blot analysis was performed as previously described ${ }^{[9]}$. Beta-actin was used to standardise the amount of protein loaded on the gel. Non-saturated bands were scanned using a densitometer, and the results were expressed as a percent of control (untreated cells).

\subsection{Quantitative assessment of BCR-ABL transcripts}

BCR-ABL expression level was determined by RQ-PCR using TaqMan probes for BCR-ABL and ABL and primers as described ${ }^{[10]}$. Absolute quantification was achieved using the Ipsogen plasmid standard curves.

\subsection{BCR-ABL mutation status}

Mass-array genotyping was performed in order to evaluate the mutation status in the BCR-ABL TK domain in K562-S and K562-R cells, using a chip-based matrix-assisted laser desorption-time of flight mass spectrometer (MALDI-TOF). Multiplex SNP assays were designed for the main 45 reported mutations that confer Imatinib resistance ${ }^{[11]}$. The whole Abl-kinase domain was screened, from amino acid 220 to $500^{[11]}$.

\subsection{Phosphor-BCR-ABL targets protein analysis}

The immediate targets of phosphor-BCR-ABL: Stat5, and crkl were evaluated. PathScan BCR-ABL Activity Assay kit (purchased from Upstate Cell Signaling). This assay was used to detect phosphor-c-Abl, phosphor-Stat5, and phosphor-Crkl. Analyses were performed according to the manufacturer's instructions.

\subsection{Quantitative assessment of WT1}

Assessment of the amount of WT1 transcript was performed by RQ-PCR using TaqMan-based technology, primers and probes were used, as described ${ }^{[12]}$. The amount of WT1 transcript was normalized with respect to the amount of ABL transcript. We used the comparative $\Delta \Delta \mathrm{Ct}$ method to calculate the RQ-PCR results. In brief, the Ct of WT1 in the resistant cells was normalized by subtracting the $\mathrm{Ct}$ of $\mathrm{ABL}\left(\Delta \mathrm{Ct} \mathrm{t}^{\text {resistant }}\right)$ and subsequently normalized by the $\Delta \mathrm{Ct}^{\text {sensitive }}$ $\left(\mathrm{Ct}_{\mathrm{WT1} 1}-\mathrm{Ct}_{\mathrm{ABL}}\right)$ of the sensitive cells, that is, $\Delta \Delta \mathrm{Ct}\left(\Delta \mathrm{Ct}{ }^{\text {resistant }}-\Delta \mathrm{Ct}^{\text {sensitive }}\right)$. The value was transformed into the relative quantitative value $\left(2^{-\Delta \Delta C t}\right)$, presented as the RQ of sensitive cells $(\%)^{[13]}$.

\subsection{Levels of P38 and phosphor-p38 proteins and the effect of inhibi- tion by SB203580}

Two primary unstained antibodies were used: anti- phosphor p38 mouse monoclonal antibody (Sigma) at 1:3500 dilution and anti- total p38 polyclonal antibody (cell-signaling) at 1: 500 dilutions. Fluorescent antibodies: goat anti-mouse (PN 926-32210) and goat anti-Rabbit (926-32211) for Odyssey system from LI-COR biosciences, USA. Western blot analysis 
was performed as previously described ${ }^{[9]}$. Beta-actin was used for normalization of the amount of protein loaded on the gel. The results are calculated as \% of phosphor-p38 from total p38. Non saturated bands were scanned using a scanning densitometer, and the results were expressed as a percent of control (untreated cells).

The involvement of p38 was examined by the effect of SB203580, a phospho-p38 inhibitor (Alexis Biochemicals San Diego, CA, USA).

\subsection{Statistical analysis}

Results are expressed as mean \pm SE. Student's t-test was performed to compare two samples. For more than two samples, one way ANOVA was used, in which all samples were compared to the corresponding control sample.

\section{Results}

\subsection{I matinib resistance, evidenced by cell viability and apoptosis}

$\mathrm{K} 562-\mathrm{S}$ and K562-R cells were exposed to Imatinib at different concentrations for $48 \mathrm{~h}$. The calculated $\mathrm{IC}_{50}$ for Imatinib was 33 times higher for K562-R than K562-S cells as shown by viability assays with trypan blue, $11 \mu \mathrm{M}$ and $0.3 \mu \mathrm{M}$, respectively (Figure 1A). Similar results were obtained with Alamar blue. Exposure to $0.5 \mu \mathrm{M}$ Imatinib resulted in a marked apoptosis and enhanced caspase activity in K562-S cells. As expected, it did not cause significant apoptosis in K562-R cells (Figures 1B and C). However, at a 16-fold higher concentration, Imatinib induced apoptosis in K562-R cells similar to that induced in K562-S cells by $0.5 \mu \mathrm{M}$ Imatinib (data not shown). Spontaneous programmed cell death with apoptotic features, as shown by DAPI staining, was higher in K562-R (10.9 \pm 0.41$)$ than in K562-S cells (5.4 \pm 0.6$)$ at $48 \mathrm{~h}$ $(p=0.0002)$. Similar results were obtained with Annexin V staining $(p<0.001$, Figure 1B). Partial reversal of the resistance occurred upon removal of Imatinib from the culture medium of K562-R cells after 20 passages. This was shown by the reduced $\mathrm{IC}_{50}$ to $2 \mu \mathrm{M}$.

A

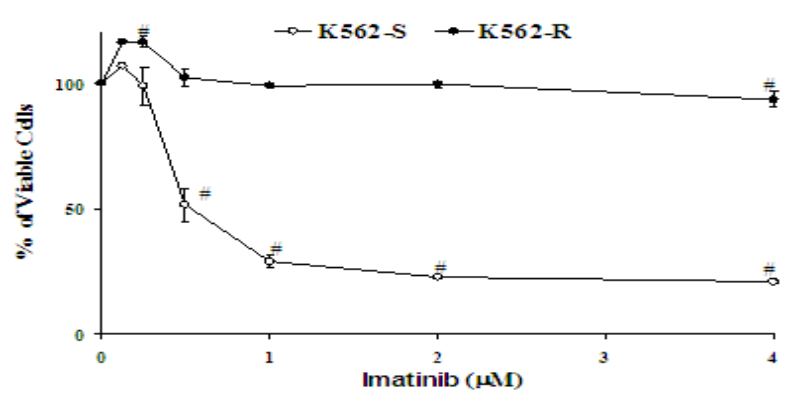

Figure 1. Viability and apoptosis of K562-S and K562-R A. Viability: K562- S $(\mathrm{O})$ and $\mathrm{K} 562-\mathrm{R}(\bullet)$ cells were incubated in the presence of $0.125-32 \mu \mathrm{M}$ Imatinib and tested for viability by trypan blue assay. Samples were withdrawn every $24 \mathrm{~h}$ for evaluation of viability. Cell viability at $48 \mathrm{~h}$ of exposure up to $4 \mu \mathrm{M}$ Imatinib is shown. B. The percentage of apoptosis was measured by Anexin V staining at $72 \mathrm{~h}$ following culturing of K562-S ( $\square$ ) and K562- R ( $)$ cells in fresh medium with the indicated concentrations of Imatinib. C. Caspase 3 activity of $\mathrm{K} 562-\mathrm{S}(\square)$ and $\mathrm{K} 562-\mathrm{R}$ cells $(\square)$ exposed to $2 \mu \mathrm{M}$ Imatinib was measured using fluorometer. The results are expressed as fold increase of the control value of caspase 3 activity per milligram protein at the indicated time of exposure. \#, $p<0.05$ difference between $\mathrm{K} 562-\mathrm{S}$ and $\mathrm{K} 562-\mathrm{R}$ cells at the same condition.
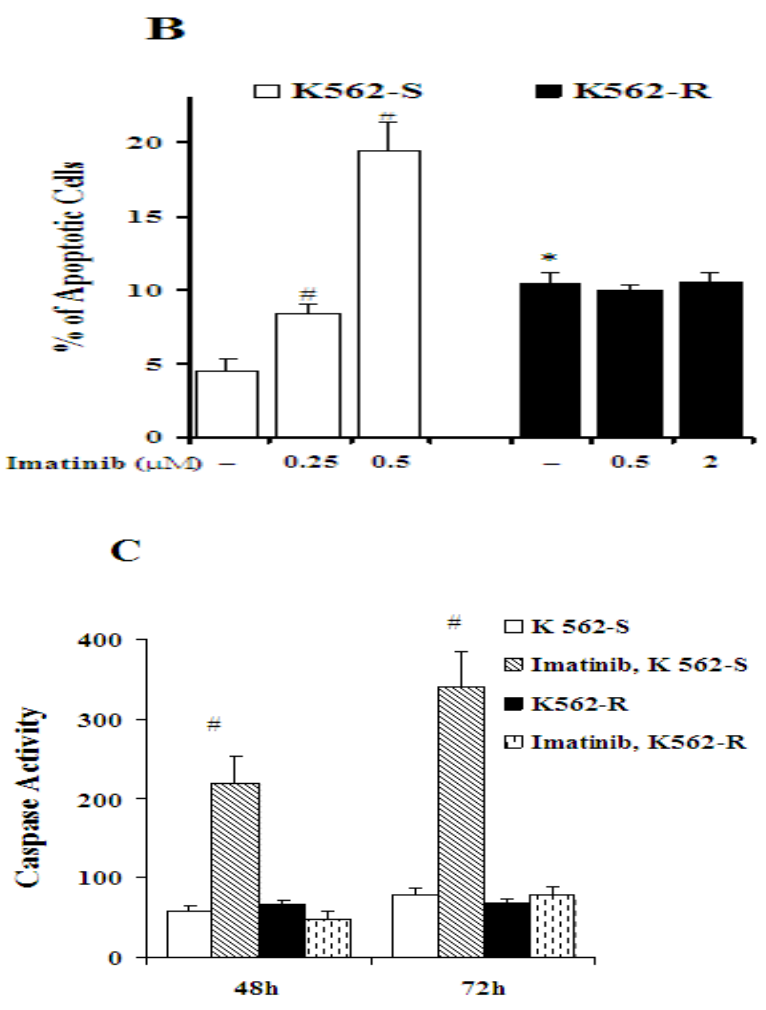


\subsection{BCR-ABL, protein and phosphor-protein, BCR-ABL transcripts and Tyrosine kinase domain mutation screening}

BCR-ABL protein, evaluated by Western blot (Figures 2A and 2B) and BCR-ABL transcripts, (Figure 2C) measured by quantitative RT-PCR, at steady state were similar in both cell lines (Figure 2, $p>0.5$ ). No significant difference was demonstrated in the phosphorylated BCR-ABL at $24 \mathrm{~h}$ of exposure to fresh medium (Figure 3). Mass-assay genotyping with MALDI-TOF did not reveal any mutations in either cell lines.

A

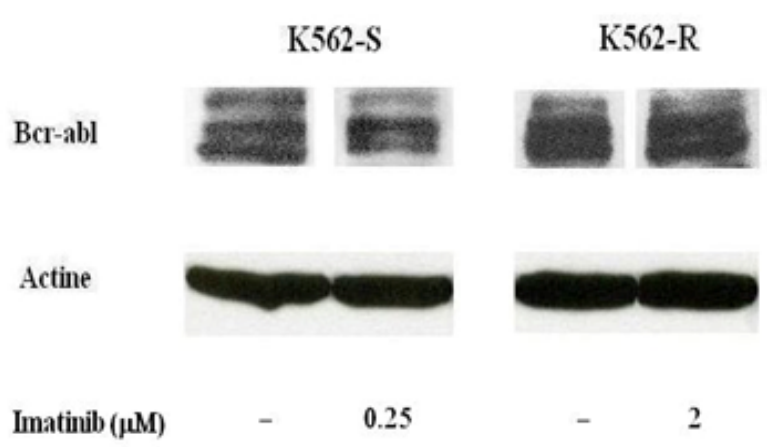

Figure 2. The expression of BCR-ABL in K562-S and K562-R cells.

The expression of total BCR-ABL in K562-S ( $\square$ ) and K562-R ( cells was determined by Western blot analysis after $48 \mathrm{~h}$ of exposure to fresh medium with or without Imatinib and normalized by $\beta$ eta-actin. A. Representative blot. B. Total BCR-ABL of 4 separate experiments (mean \pm SE). C. BCR-ABL transcripts normalized by $\mathrm{ABL}$ of 3 separate experiments $($ mean $\pm \mathrm{SE})$.
B

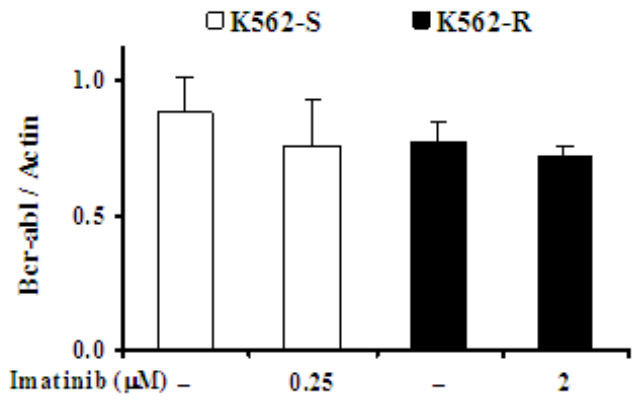

C $\square$ K562-S $\square$ K562-R

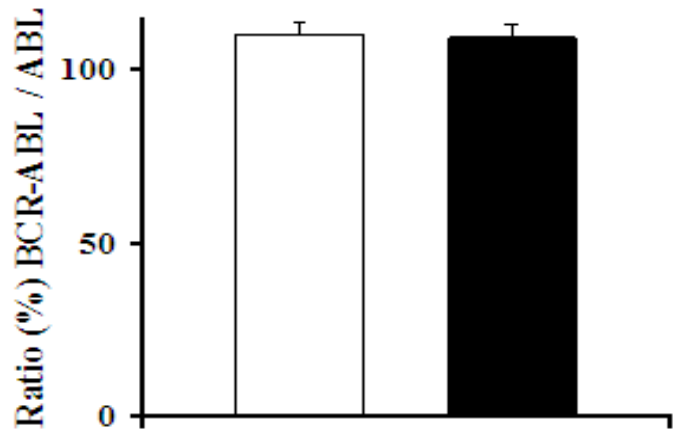

Exposure of the cells to Imatinib at the indicated concentrations for $24-72 \mathrm{~h}$ had no significant effect on BCR-ABL protein levels in both cell lines. Figure $2 \mathrm{~B}$ shows the results at $48 \mathrm{~h}$. Levels of phosphorylated BCR-ABL were reduced in both cell lines by about $35 \%$ after $20 \mathrm{~min}$ of exposure to $2 \mu \mathrm{M}$ Imatinib and about $50 \%$ after $24 \mathrm{~h}$ of exposure (Figure 3 ).

\subsection{Phospho-Stat5 and phosphor-crkl}

The immediate targets of phosphor-BCR-ABL: Stat5 and crkl were phosphorylated similarly in both cell lines. Exposure to Imatinib for $20 \mathrm{~min}$ and $24 \mathrm{~h}$ induced similar changes in these proteins in both cell lines as evaluated by densitometry (Figure 3).

\subsection{Effect of HDACI}

In order to determine the specificity of Imatinib resistance mechanism in K562-R cells, K-562-S and K562-R cells were exposed to other agents, such as Pivaloyl-oxymethyl Butyrate, a HDACI and arsenate trioxide $\left(\mathrm{As}_{2} \mathrm{O}_{3}\right)$. Exposure to 2.0 
$\mu \mathrm{M}$ of $\mathrm{As}_{2} \mathrm{O}_{3}$, showed reduction in viability (about 75\%) and apoptosis (about 26\%) in both cell lines. However, HDACI induced 2 times higher loss of viability in K562-R cells (35\% vs. 16\% for K562-R and K562-S, respectively, $p=0.0001$ ) and higher apoptosis (Figure 4A).

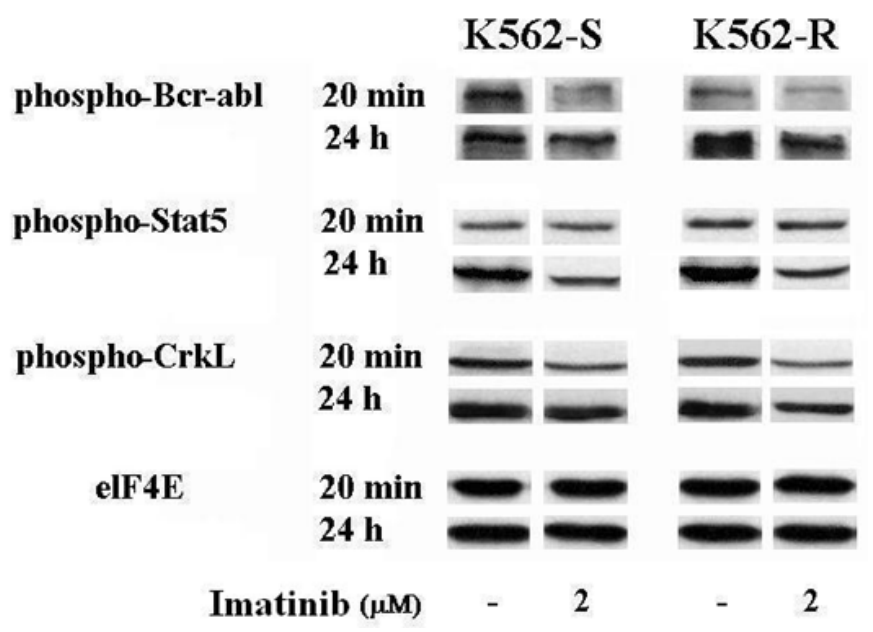

\subsection{WT1 gene expression}

WT is highly expressed in leukemic cells and induced by oncogenic signalling from BCR-ABL. The expression of WT1 was reduced by $63 \%$ in K562-R cells compared to K562-S cells ( $37 \pm 4 \%$ in K562-R compared to K562-S, $p<0.00001$ ). The addition of $0.25 \mu \mathrm{M}$ Imatinib reduced the expression of WT1 in K562-S cells by $67 \%$, but it failed to affect the K562-R cells (Figure 4B). K562-R and K562-S showed a similar reduction (35\%) in the expression of WT1, in the presence of the same concentration of HDACI (data not shown).

A

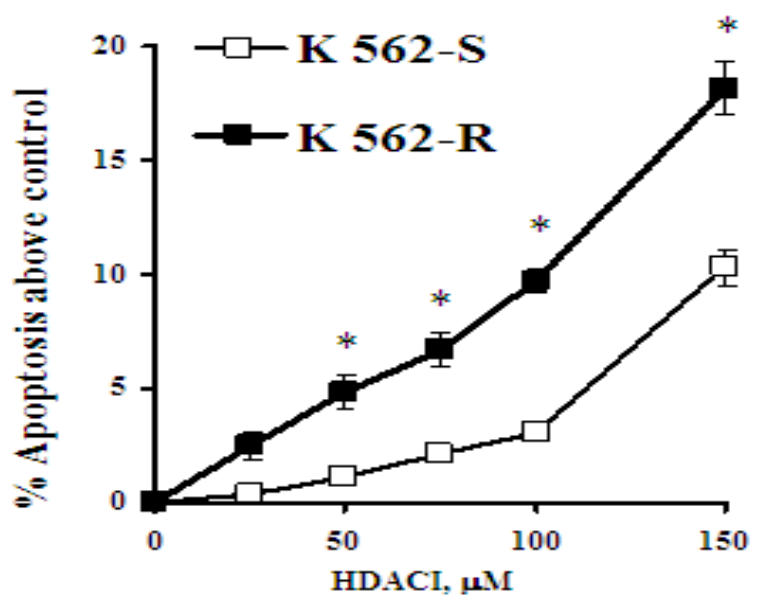

$\mathbf{B}$

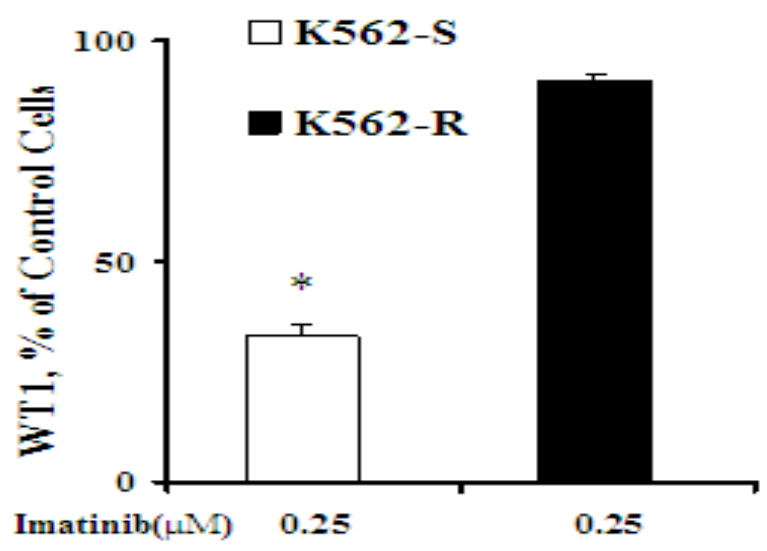


C

$\square \mathbf{K 5 6 2 - S}$

n K562-R

产

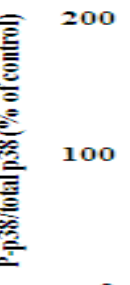

Imatinib( $\mu \mathrm{M})$ HDACI $\mu$ M)

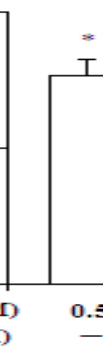

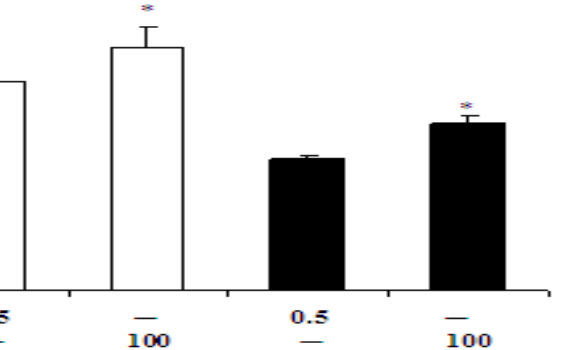

$\mathbf{D}$

K562-S

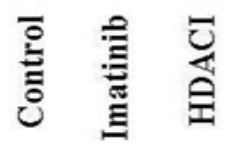

P-p38

Total p38
K562-R
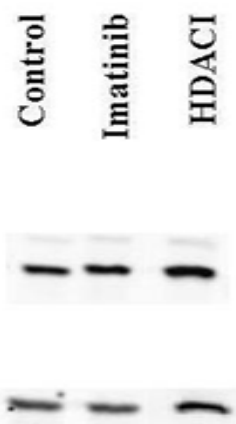

Figure 4. Apoptosis induction, WT1 expression and the levels of phosphor-p38.

A. The percentage of apoptosis was determined by Anexin V staining in K562-S ( $\square$ ) and K562- R ( $\square$ ) cells exposed to various concentrations of HDACI. Data are presented as mean $\pm \mathrm{SE}$ of 4 experiments. B. The expression of WT1 normalized by ABL in both cell lines following exposure to Imatinib. C. The expression of phosphor-p38 normalized by total p38 protein in K562-R and K562-S cells after $48 \mathrm{~h}$ of exposure to imatinib and HDACI is shown (mean $\pm \mathrm{SE}$ of 4 experiments) ${ }^{*} p<0.05$. D. A representative Western blots after $48 \mathrm{~h}$ of exposure to fresh medium with or without $100 \mu \mathrm{M}$ HDACI and $0.5 \mu \mathrm{M}$ Imatinib.

A

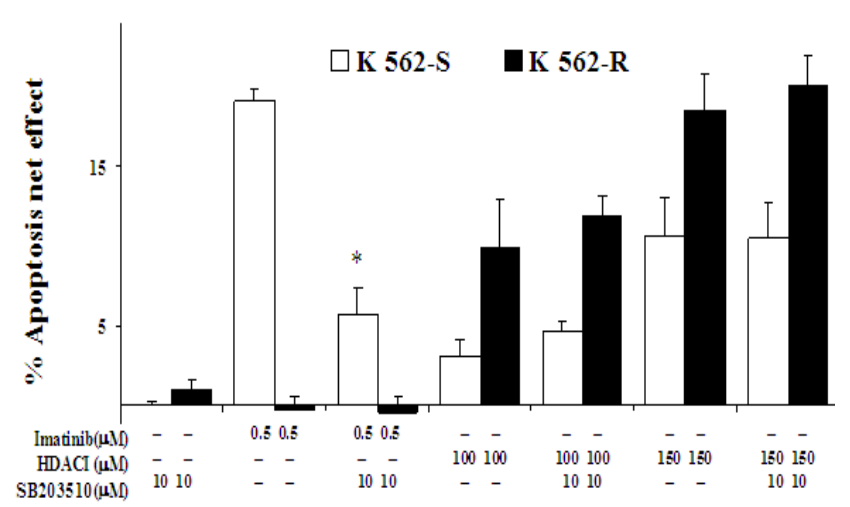

B

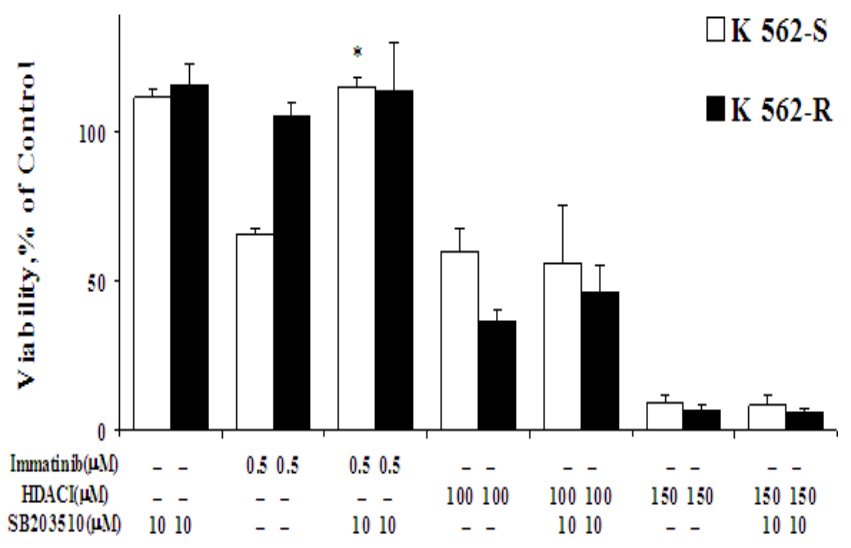

Figure 5. The effect of SB203510 on the response to HDACI and Imatinib.

Cells were incubated in the presence or absence of Imatinib and HDACI at the indicated concentrations with or without the SB203510 for 3 days. A. Apoptosis was determined by Anexin V staining at $72 \mathrm{~h}$. B. Cell viability was determined by trypan blue assay after $48 \mathrm{~h}$. The results represent the percentage of control value. The number of cells $/ \mathrm{mL}$ in control samples was $1.3 * 10^{6}$ and $1.27 \times 10^{6}$ for K562-S and K562-R respectively. ${ }^{*} p<0.05$.

\subsection{Phosphorylated p38}

The levels of phosphor-p38 MAPK at steady state were by $73 \pm 14 \%$ higher in K562-R than in K562-S cells as shown by Western blot analysis $(p<0.006)$. 
Exposure of K562-S cells to Imatinib resulted in a 50\% increase in phosphor-p38 from control values $(p<0.001)$, while K562-R cells showed only an insignificant enhancement of 5\% (Figure 4C). In both cell lines, the exposure to HDACI caused an increase in the levels of phosphor-p38 protein. The increase was higher in K562-S cells, Figure 4D $(p<0.02)$.

\subsection{I nhibition of phosphorylated p38 by SB203580}

In order to shed light on the involvement of p38 in response to Imatinib and HDACI, in K562-R cells, we examined the effect of p38 inhibition on apoptosis and viability.

SB203580, a phosphor- p38 inhibitor, enhanced the viability of K562-S and K562-R cells by $25 \%$ and $32 \%$ respectively $(p=0.007)$. The combination of the inhibitor with Imatinib enhanced cell viability and reduced apoptosis induction in K562-S cells compared to Imatinib $(p<0.001)$. Imatinib in combination with the inhibitor had no effect in K562-R cells (Figure 5)

Neither the apoptosis induction nor the viability losses by HDACI were affected by the inhibitor in both cell lines.

\section{Discussion}

TK Domain inhibitors are the most effective agents in the treatment of CML. Nevertheless, the sequence of molecular events downstream to the blockage of the TK domain is, in part, still unknown. Although most cases of Imatinib resistance stem from kinase domain mutations and/or over expression of the BCR-ABL gene, BCR-ABL-independent mechanisms have been recognized as well ${ }^{[14,15]}$. Our data show that BCR-ABL protein, phosphor-protein and transcripts levels in the K562-R cells were similar to those of K562-S cells. Same levels of the immediate target proteins of phosphor-BCR-ABL (phosphor-Stat5 and phosphor-crkl) were shown in both cell lines. These suggest that K562-R cells are BCR-ABL-independent. Furthermore, the absence of mutations in the Abl kinase catalytic domain in the Imatinib-resistant variant excludes the possibility that this resistance was due to mutation in the TK domain.

Our data show that the expression of MDR- Pgp protein (CD243-RPE) and the activity (determined by Rh123 efflux) was similar in both cell lines (data not shown). Therefore, MDR is probably not involved in the observed resistance. However, interesting data arises from comparing K562-R and K562-S cells. K562-R cells were shown to have a more apoptotic phenotype than K562-S cells. Phospor-p38 was higher in K562-R compared to K562-S. Enhanced expression of Phospor-p38 induced by Imatinib in BCR-ABL expressing cells has been shown by Parmar $\&$ al. Their findings suggested for the first time the involvement of p38 pathway in the response to Imatinib ${ }^{[16]}$. Moreover, also WT1 expression was lower significantly in K562-R compared to K562-S. These changes in Phospor-p38 and WT1 may explain the elevated basal apoptosis of K562-R.

The induction of apoptosis in K562-R cells, by Pivaloyl-oxymethyl Butyrate, a HDACI, and Arsenate trioxide, but not by Imatinib, suggests that the apoptosis pathway is altered only in response to Imatinib. These results indicate a partial interference in the apoptosis cascade in these resistant cells.

Interestingly, higher apoptosis was induced by HDACI in K562-R cells and higher phospor-p38 levels were found in these cells compared to K562-S cells. Parmar \& al. ${ }^{[16]}$ and Olaf \& al. ${ }^{[17]}$ have shown enhanced phospor-p38 in response to Imatinib and butyrate and suggested that phospor-p38 is a mediator of their anti-leukemic effect. It was shown that the proper function of $\mathrm{p} 38$ family is required for regulation of apoptosis, cell cycle arrest and induction of cell differentiation in response to stress signals ${ }^{[7]}$. Therefore, involvement of $\mathrm{p} 38$ in the apoptosis induced by HDACI in K562-R cells was investigated. HDACI induced phospor-p38 only slightly in K562-R cells in comparison to its effect on K562-S cells. This could stem from the already high phospor-p38 in K562-R cells. As expected, inhibition of phospor-p38 by pyridinyl imidazole compound (SB203510) inhibited Imatinib induced apoptosis in K562-S. Similar suppression of Imatinib effect, by inhibition of phospor-p38, was demonstrated in primary leukemic cells from CML patients ${ }^{[16]}$. But inhibition of 
phospor-p38 had no effect neither on viability nor on apoptosis induction by HDACI in both K562-R and K562-S cells. Our data suggests that phospor-p38 does not play a major role in the apoptosis induced by this HDACI in K562-S and K562-R cells.

In summary, we describe a CML Imatinib-resistant, BCR-ABL independent, cell line with high levels of phosphor-p38. Elevated levels of apoptosis induced by HDACI in these cells were demonstrated. Further investigation on the role of proteins associated with apoptosis pathways may have important implications, in future design, of new modalities either to overcome resistance or potentiate TKI efficacy.

\section{Acknowledgements}

We thank Prof. Ruth Koren from Felsenstein Medical Research Center, Tel Aviv University, Israel for the fruitful discussions.

Mutation analysis was performed at Hematology laboratory in Shiba medical center.

\section{References}

[1] Ben-Neriah Y, Daley GQ, Mes-Masson AM, Witte ON, Baltimore D. The chronic myelogenous leukemia-specific P210 protein is the product of the BCR/ABL hybrid gene. Science. 1986; 233: 212-4. PMid:3460176 http://dx.doi.org/10.1126/science.3460176

[2] White DL, Saunders VA, Dang P, Engler J, Zannettino AC, Cambareri AC, et al. OCT-1-mediated influx is a key determinant of the intracellular uptake of omatinib but not nilotinib: reduced OCT-1 activity is the cause of low in-vitro sensitivity to imatinib. Blood. 2006; 108(2): 697-704. PMid:16597591 http://dx.doi.org/10.1182/blood-2005-11-4687

[3] Danhauser-Riedl S, Warmuth, M,Druker BJ, Emmerich B, Hallek M. Activation of Src kinases p53/56 Lyn and p59hck by p210bcr/abl in myeloid cells. Cancer Res. 1996; 56: 3589-96. PMid:8758931

[4] Weisberg E, Manley PW, Cowan-Jacob SW, Hochhaus A, Griffin JD. Second generation inhibitors of BCR ABL for the treatment of imatinib-resistant chronic myeloid leukemia. Nat Rev Cancer. 2007; 7: 345-56. PMid:17457302 http://dx.doi.org/10.1038/nrc2126

[5] Yu C, Rahmani M, Almenara JU, Subler M, Krystal G, Conrad D, et al. Histone deacetylase inhibitors promote STI571-mediated apoptosis in STI571-sensitive and resistant Bcr/Abl human myeloid leukemia cells. Caner Res. 2003; 63: 2118-26. PMid:12727828

[6] Svensson E, Vidovic K, Lassen C, Richter J, Olofsson T, Fioretos T, Gullberg U. Deregulation of the Wilms' tumour gene 1 protein (WT1) by BCR/ABL1 mediates resistance to imatinib in human leukaemia cells. Leukemia. 2007; 21(12): $2485-94$. PMid:17728783 http://dx.doi.org/10.1038/sj.leu.2404924

[7] Platanias LC. Map kinase signaling pathways and hematologic malignancies. Blood. 2003; 101(12): 4667-78. PMid:12623839 http://dx.doi.org/10.1182/blood-2002-12-3647

[8] Mahon FX, Deininger MWN, Schultheis B, Chabrol J, Reiffers J, Goldman JM, Melo JV. Selection and characterization of BCR-ABL positive cell lines with differential sensitivity to the tyrosine kinase inhibitor STI571: diverse mechanism of resistance. Blood. 2000; 96: 1070-9. PMid:10910924

[9] Rabizadeh E, Merkin V, Belyaev I, Shaklai M, Zimra Y. Pivanex, a histone deacetylase inhibitor induces changes in BCR-ABL expression and is effectively combined with STI571 in chronic myelocytic leukemia cell line. Leuk Res. 2006; 31(8): $1115-23$. PMid:17267032 http://dx.doi.org/10.1016/j.leukres.2006.12.015

[10] Gabert J, Beillard E, van der Velden VHJ, Bi W, Grimwade D, Pallisgaard M, et al. Standardization and quality control studies of 'real-time' quantitative reverse transcriptase polymerase chain reaction of fusion gene transcripts for residual disease detection in leukemia - A Europe against cancer program. Leukemia. 2003; 17: 2318-75. PMid:14562125 http://dx.doi.org/10.1038/sj.leu.2403135

[11] Nante A, Amariglio, N, Koren-Michowitz M, Ashur-Fabian O, Nagler A, et al. High-throughput, sensitive and quantitative assay for the detection of BCR-ABL kinase domain mutations. Leukemia. 2007; 21: 1318-21. PMid:17330094 http://dx.doi.org/10.1038/sj.leu.2404635

[12] Siehl JM, Reinwald M, Heufelder K., Menssen HD, Keilholz U, Thiel E. Expression of Wilms tumor gene 1at different stages of acute myeloid leukemia and analysis of its major splice variants. Ann Hematol. 2004; 83: 745-50. PMid:15340762 http://dx.doi.org/10.1007/s00277-004-0941-0 
[13] Pfaffl MW. A new mathematical model for relative quantification in real-time RT-PCR. Nucl Acids Res. 2002; 29 (9): e45. http://dx.doi.org/10.1093/nar/29.9.e45

[14] Azam M, Daley GQ. Anticipating clinical resistance to target-directed agents: the BCR-ABL paradigm. Mol Diagn Ther. 2006; 10(2): 67-76. http://dx.doi.org/10.1007/BF03256446

[15] Lee SM, Bae JH, Kim MJ, Lee HS, Lee MK, Chung BS, et al. BCR-ABL-independent imatinib-resistant K562 cells show aberrant protein acetylation and increased sensitivity to histone deacetylase inhibitors. J Pharmacol Exp Ther. 2007; 322: $1084-92$. PMid:17569822 http://dx.doi.org/10.1124/jpet.107.124461

[16] Parmar S., Katsoulidis, E. Verma, A. Li Y., Sassano, A. Lal, L. Majchrzak, B. Ravandi F., Martin Tallman, S. Eleanor Fish, N. and Platanias L. C. Role of the p38 Mitogen-activated Protein Kinase Pathway in the Generation of the Effects of Imatinib Mesylate (STI571) in BCR-ABL-expressing Cells. The J. Biol. Chem. 2004; 279: 25345-25352. PMid:15056660 http://dx.doi.org/10.1074/jbc.M400590200

[17] Olaf W, Sand K, Pekrun A. Butyrate-induced erythroid differentiation of human K562 leukemia cells involves inhibition of ERK and activation of p38 MAP kinase pathways. Blood. 2000; 95: 2391-6. 